\title{
Corpo-Acontecimento: um contraponto ao corpo formado em nossas escolas
}

Body-Happening: a counterpoint to the body formed in our schools

Aline Silva Brasil ${ }^{1}$

Mariana Baruco Machado Andraus ${ }^{2}$ 


\section{Resumo}

Este ensaio pretende colocar em diálogo concepções de vida e de arte e o contexto formativo que temos construído ao longo da história, particularmente na instituição escolar. Partindo da crítica de Foucault à formação dos "corpos dóceis" e às instituições disciplinares, desenvolvemos o conceito de "Corpo-Estagnado" e propomos, por meio de uma abordagem improvisacional na arte tanto na experiência em dança das autoras quanto na obra de Henri Cartier-Bresson, percebido neste trabalho como um sensível fotógrafo de "momentos" -, a possibilidade de ter o "Corpo-Acontecimento" como horizonte da formação do sujeito.

Palavras-chave: Corpo-estagnado; Corpo-acontecimento; Improvisação; Formação do sujeito

\section{Abstract}

This essay intends to stablish a dialogue between life and art conceptions, and the formative context that have been built through history, particularly at educational institutions. Building on Foucault's critique to "docile bodies" and disciplinary institutions, we developed the concept of "Stagnant Body" and propose, through an improvisational approach in art - such in dance experience of the authors as in Henri Cartier-Bresson's work, perceived here as a sensitive "moments" photographer -, the possibility to have the "Happening-Body" as aim in one's formation.

Keywords: Stagnant-body; Happening-body; Improvisation; One's formation

\footnotetext{
${ }^{1}$ Estudante Especial no Programa de Pós-Graduação em Artes da Cena da Universidade Estadual de Campinas (UNICAMP) Campinas SP. enilabrasil@hotmail.com

${ }^{2}$ Professora doutora do Curso de Graduação em Dança (Departamento de Artes Corporais, Universidade Estadual de Campinas). Doutorado em Artes da Cena, Pós-Doutorado em Educação Coordenadora do Programa de Pós-Graduação em Artes da Cena da Universidade Estadual de Campinas. m andraus@iar.unicamp.br
} 


\section{A escola e a formação do "Corpo-Estagnado"}

[Nos] esquemas de docilidade, em que o século XVIII teve tanto interesse, o que há de tão novo? Não é a primeira vez, certamente, que o corpo é objeto de investimentos tão imperiosos e urgentes; em qualquer sociedade, o corpo está preso no interior de poderes muito apertados, que lhe impõem limitações, proibições ou obrigações. Muitas coisas entretanto são novas nessas técnicas. A escala, em primeiro lugar, do controle: não se trata de cuidar do corpo, em massa, grosso modo, como se fosse uma unidade indissociável mas de trabalhá-lo detalhadamente; de exercer sobre ele uma coerção sem folga, de mantê-lo ao nível mesmo da mecânica - movimentos, gestos atitude, rapidez: poder infinitesimal sobre o corpo ativo. O objeto, em seguida, do controle: não, ou não mais, os elementos significativos do comportamento ou a linguagem do corpo, mas a economia, a eficácia dos movimentos, sua organização interna; a coação se faz mais sobre as forças que sobre os sinais; a única cerimônia que realmente importa é a do exercício. [...]. Esses métodos que permitem o controle minucioso das operações do corpo, que realizam a sujeição constante de suas forças e lhes impõem uma relação de docilidade-utilidade, são o que podemos chamar as "disciplinas". Muitos processos disciplinares existiam há muito tempo: nos conventos, nos exércitos, nas oficinas também. Mas as disciplinas se tornaram no decorrer dos séculos XVII e XVIII fórmulas gerais de dominação (Foucault, 1977, p. 126).

Ao propormos pensar e discutir a temática do corpo e da escola (enquanto principal instância educacional de nossa sociedade) é inevitável nos questionarmos acerca dos paradigmas do pensamento humano que vêm prevalecendo, ao longo dos anos, e que legitimam determinadas formas de se ver o mundo e o que nele há, determinadas formas de se relacionar com ele e de viver dentro dele, bem como determinadas formas de se pensar o corpo e de formá-lo.

É no contexto histórico da modernidade que nasce o projeto de escola que ainda temos em nossos dias e que traduz, na sua própria estrutura e organização interna, um olhar reducionista lançado ao mundo e ao corpo. Bebendo da fonte dos ideais iluministas, a crença exacerbada na razão enquanto aquilo que faz o homem ser homem faz da instituição escolar o principal espaço para a formação de "seres pensantes". Forma-se, assim, um tipo específico de homem que parte do ideal racionalista cartesiano: um homem apartado de seu corpo, corpo este visto como algo a ser disciplinado (Foucault, 1977). Conforme elucida Portocarrero 2004, p. 170),

Foucault estuda a constituição, a partir do século XVIII, de saberes e práticas que ordenam as multiplicidades humanas e objetivam o sujeito, individualizando-o e homogeneizando as diferenças através da disciplina e da normalização - práticas de divisão do sujeito em seu interior e em relação aos outros. Trata-se de saberes e práticas que atingem a realidade mais concreta do indivíduo, seu corpo, e que, devido à sua estratégia de expansão por toda a população, funcionam como procedimentos abrangentes de inclusão e exclusão social, que constituem um processo de dominação com base no binômio normal e anormal.

\footnotetext{
${ }^{3} \mathrm{O}$ termo "estagnado" refere-se, aqui, muito mais à ideia de obstáculos que impedem o fluir natural dos acontecimentos do que à ideia de ausência de movimento. Um corpo estagnado poderia estar em movimento, mas um movimento controlado, automatizado, inautêntico, fora do campo de imanência deste mesmo corpo, o que o impede de "acontecer".
} 
Nesse sentido é que trazemos, aqui, a ideia de "Corpo-Estagnado"3 enquanto o corpo formado em nossas escolas. Com efeito, estamos falando da noção de instituição escolar enquanto entidade disciplinadora, a escola tradicional - cuja estrutura ainda se replica no panorama educacional brasileiro, salvaguardadas as ainda minoritárias instituições que rompem com o modelo disciplinar:

A disciplina organiza o espaço através de uma repartição dos indivíduos; controla a atividade através do controle do tempo; especifica o indivíduo generalizando -o através de uma vigilância hierárquica; organiza as diferenças através de uma sanção normalizadora e reproduz e produz saber através do exame (Portocarrero, 2004, p. 172).

Difícil não associar ao atual momento do cenário educacional brasileiro, no qual se recoloca a discussão sobre ideologia na escola, ignorando-se que o horário rígido de entrada e saída, a disposição insistentemente enfileirada das carteiras, o uso de uniformes, entre outras "normas", consistem puramente em ideologias estagnadoras e que parecem ter e manter no horizonte a formação de corpos estagnados. No entanto, não é escopo deste artigo discutir o corpo especificamente na educação ou na escola, mas, a partir do corpo nela produzido, elaborar a noção de Corpo-Acontecimento como espaço de criação e respiro, de renovação paradigmática que se delineia nos horizontes das pesquisas em artes da cena, vislumbrando o saudável efeito que poderiam trazer aos corpos em formação.

Por que Corpo-Estagnado? Ora, na medida em que se distancia o sujeito de seu próprio corpo, distancia-se o sujeito de seu próprio fazer, de sua própria ação, de seu campo de imanência; distancia-se o sujeito da capacidade de fazer o seu tempo e a sua história estagnando-o em um tempo deslocado do presente, do instante, do acontecimento em que ele vive. Essa estagnação é o que nossas escolas têm produzido, fincadas ainda no paradigma da modernidade, nos ideais iluministas de mundo e de corpo.

\section{O paradigma da modernidade}

Corpo, neste paradigma, é apenas uma extensão das coisas objetivas do mundo, e não tem nada a ver com a essência humana. $O$ corpo não é sujeito, é objeto. $A$ razão, sim, é sujeito e corresponde à humanidade. Daí a máxima cartesiana: “Penso, logo existo".

O homem, enquanto ser pensante, é algo totalmente alheio aos seus aspectos corporais; contudo, o ser humano vive uma curiosa situação, sua existência decorre de uma mescla entre substâncias, já que ele está inserido no corpo, vinculado ao corpo, como um anjo dentro de uma máquina (Barrenechea, 2011, p.10).

A imagem de um anjo dentro de uma máquina é a mesma imagem de uma alma dentro de um corpo, de uma substância dentro de uma matéria, de um dualismo irredutível que considera a totalidade do ser humano em apenas uma de suas partes. Sendo apenas uma matéria, o corpo foi aberto com bisturis, dissecado e compreendido em suas partes cada uma com funções bem específicas; o corpo foi cate- 
gorizado e classificado a partir e através de suas funcionalidades orgânicas. O corpo foi chamado de Organismo.

O homem olhou para si mesmo desta forma em nome do racionalismo predominante, tornando-se um sujeito pensante (externo) a olhar o seu próprio corpo-objeto. Essa cisão entre corpo e pensamento se perpetua ainda nas nossas escolas de hoje, mesmo com todas as tentativas de desconstrução desta concepção empreendidas após a metade do século $\mathrm{XX}^{4}$.

Se a razão foi considerada por tanto tempo enquanto a própria essência humana, dividindo e separando o homem de si mesmo (que é o seu próprio corpo), as instituições escolares cuidarão de perpetuar esta forma de conhecer o mundo: uma forma reducionista e fragmentária na qual tudo se encontra separado, dividido, compartimentalizado, categorizado dentro de funções específicas, inclusive os corpos que ali estão e que são agentes do processo de aprendizagem.

Uma escola que continua dividindo o conhecimento em assuntos, especialidades e subespecialidades, fragmentando o todo em partes, separando o corpo em cabeça, tronco e membros, as flores em pétalas, a história em fatos isolados, sem se preocupar com a integração, a interação, a continuidade e a síntese [...]. De acordo com esta visão conteúdo e produto são mais importantes que o processo de construção do conhecimento (Moraes, 1997, p. 51).

A escola, ao ensinar a ideia de Corpo-Organismo, também se propõe como um pequeno órgão com a sua funcionalidade específica dentro de um todo: o Mundo-Organismo. É justamente a partir desta ação de nomear o corpo, de entificá-lo na forma de um Organismo, que se constrói o que estamos chamando neste texto de "Corpo-Estagnado". O corpo entificado é um corpo estagnado na medida em que é apartado de si mesmo, de seu campo de imanência em nome de uma transcendência (uma ideia que sempre se faz sobre ele e não por ele). O corpo entificado é um corpo estagnado por ser retirado de seu devir, de seu movimento.

\section{O ser (corpo) entificado como Organismo}

Corpo e mundo adquiriram uma predicação específica, receberam propriedades e qualidades que são próprias desta ideia de Organismo. E é claro que a escola, enquanto uma das várias instituições presentes neste mundo, também foi construída a partir e nesta entificação. Todo processo de entificação do ser passa pela constituição de um "eu" específico, com suas subjetivações e significâncias próprias.

A partir do momento em que se estabelece na história do pensamento humano este Ente-Organismo, estabelecem-se determinados atributos sobre o mundo e sobre o homem e que, neste caso, correspondem aos atributos do paradigma da mo

\footnotetext{
${ }^{4} \mathrm{O}$ século $\mathrm{XX}$, especialmente a sua segunda metade, é um período, no contexto brasileiro, marcado por novas ideias e concepções em torno da escola, por críticas ao sistema tradicional de ensino, pelo processo de democratização da educação, por uma forte efervescência política, social e cultural no qual surgiram outras perspectivas sobre a educação tal como a perspectiva de Paulo Freire. Ainda, assim, as nossas escolas de hoje carregam um legado histórico pesado que é, justamente, o da cisão entre corpo e mente.
} 
dernidade que ainda estamos a reproduzir em nossos discursos e em nossas ações.

É como passarmos a ver tudo atrás de uma lente específica que corresponde a processos de categorizações e subcategorizações dentro de um sistema maior. A delimitação desses compartimentos vários assegura a compreensão acerca da funcionalidade do todo, evitando riscos de disfunções. Essa necessidade surge a partir do momento em que se entende que o corpo e o mundo devem funcionar de determinada forma e que este funcionamento deve ser controlado.

A escola foi uma das instâncias sociais criadas para assegurar esta funcionalidade do mundo e dos corpos nele inseridos, formando homens pensantes, distanciados de seu ser (corpo), entificados por meio de subjetivações e significações rígidas construídas de fora para dentro e de cima para baixo. A escola nos dá a resposta sobre quem somos ou deveríamos ser.

Nesse sentido, o processo de aprendizagem se vê engessado dentro de uma expectativa. A expectativa sobre uma aprendizagem não é um problema em si; ela se torna um problema ou uma questão a ser pensada na medida em que cria formas específicas e rígidas deste processo acontecer em nome de um ideal de resultado ao qual se deve chegar a todo custo.

Em nossas escolas o corpo ainda é algo sem voz. Já não existem palmatórias, os professores já não são considerados os únicos detentores do conhecimento e os alunos podem dizer o que pensam em sala de aula, contudo esses corpos pouco falam de si mesmos fora de uma expectativa já criada sobre eles. Tanto é que os corpos que habitam as escolas de nossos dias são corpos cansados e saturados desta organização educacional e de uma vida voltada a objetificá-los para o mercado. São corpos cansados porque estagnados, retirados de seu movimento próprio e inseridos em uma expectativa de movimento externa a eles.

Em vez de produzir as transformações necessárias para o desenvolvimento harmonioso do ser humano, a educação atual continua gerando padrões de comportamento preestabelecidos, com base em um sistema de referência que nos ensina a não questionar, a não expressar o pensamento divergente, a aceitar passivamente a autoridade, a ter certeza das coisas (Moraes, 1997, p. 50).

Falar em processos dentro do sistema educacional que sistematizamos ao longo dos anos parece ser um contrassenso. Isso porque o que as escolas tendem a valorizar no que diz respeito à aprendizagem de seus alunos é muito mais o resultado, e o resultado tende a ser algo específico esperado. Há pouco ou quase nenhum espaço para o erro. O erro é sempre um erro e não a possibilidade de um acerto, visto de outro ângulo. A forma como as avaliações acontecem é um dos retratos disso. Reduzir a aprendizagem a um número é reduzir o ser humano a uma determinada expectativa que, por vezes, não diz nada a ele próprio e ao que ele almeja enquanto sujeito capaz de construir sua própria história.

Mesmo em uma relação professor-aluno que procura a superação de uma relação dualista e reducionista, propondo uma relação dialética na qual o corpo readquire o seu caráter de sujeito ativo e de sujeito de voz, a forma como as escolas são organizadas pouco dá espaço para que nesta relação dialógica entre os sujeitos da aprendizagem o corpo possa superar-se naquilo que ele é, naquilo que esperam que 
ele seja, naquilo que já foi delimitado e colocado de antemão. O corpo não é visto enquanto um processo e dele se espera resultados muito precisos; o corpo é preenchido e pouco se permite um transbordar-se ou um ultrapassamento de seus limites.

A expectativa que se cria sobre o corpo a ser educado tende a ser a expectativa de formação deste Corpo-Organismo, concepção que ainda paira em nossas ações. Cria-se, portanto, uma expectativa sobre o "eu", sobre as subjetivações a serem formadas. E é na relação com o "outro" (seja este outro o mundo, a sociedade, os pais, a escola, os professores) que adquirimos a noção desta expectativa. Quando chegamos ao mundo já existe certo script a seguir e, em geral, quem acaba fugindo dele de alguma forma não está isento de algum tipo de julgamento ou até rejeição. O sistema escolar rejeita ainda diversos alunos rotulados como fracassados. Mas o fracasso é de quem?

O fracasso é apenas o resultado de uma expectativa instituída e lançada sobre o corpo e que ignora o caminho, o movimento, o devir inerente a este mesmo corpo. O fracasso é a busca irracional e desenfreada de uma segurança e controle sobre todo tipo de processo que tem algo a dizer por conta própria. O fracasso é justamente esta ação de não ouvir o movimento próprio e inerente ao corpo, que nunca é um corpo só, mas vários, e estabelecer um único jeito de se movimentar, de se falar, de se chegar a um determinado lugar. O fracasso, enfim, é querer o uno a todo custo atropelando a multiplicidade que somos. $O$ outro se torna o nosso espelho a quem devemos ser iguais; ele se torna a nossa referência de ser e existir no mundo, a nossa busca, e esquecemos que somos diferentes do outro e que traçaremos caminhos diferentes dos dele, mesmo que venhamos a passar pelos mesmos lugares.

Para esse eu, o princípio era o outro. É este outro que oferece ao eu uma imagem
unificada e totalizante, organizada e bela para ser objeto de amor e cuidados ga-
rantindo assim sua segurança. Imagem sem faltas, pois da falta não há imagem.
Eu sem falta. Eu amparado pela forma apreendida no olhar do outro. O preço a
ser pago pelo eu a este outro, por sua existência, é da ordem do impagável. As-
sim, não tendo como saldar sua dívida e obter sua alforria, o eu se vê obrigado
a seguir à risca o script que o desejo do outro lhe dita, tentando garantir o amor
desse outro onipotente e, com isso, garantir sua segurança (Amaral, 2002, p. 73).

De alguma forma, aprendemos a ter pavor da falta, dos espaços vazios que podem surgir dentro de nós. Não podemos ter dúvida de nada, não podemos colocar em questão as coisas consideradas já como "certas". Ao definirmos o que é "normal" e "anormal" no mundo, vivemos apenas em busca desta normalidade inventada ou desta certeza ridiculamente considerada como absoluta. Não nos permitimos olhar para nós mesmos e nos ver incompletos, imprecisos, inacabados e constantemente abertos para sermos modificados. Não prestamos atenção ao campo de imanência sob o qual nos fazemos e nos refazemos a todo instante. Queremos nos ver prontos, pois assim, no mundo, teremos espaço dentro do amplo Organismo que ele se configura. Teremos papel a desempenhar, teremos função, teremos uma identidade e nos sentiremos existindo.

Tudo isso, no entanto, é uma grande farsa na medida em que nos descobrimos incompletos e dinâmicos, na medida em que olhamos para dentro de nós e enxergamos sempre espaços vazios para preenchermos - e não só preenchermos até nossos 
limites, mas ultrapassá-los. Quando conhecemos o transbordo, o preenchimento se torna pouco e passa a ser apenas uma convenção de um desejo absoluto criado de fora pra dentro e estendido até nós. Transbordar é acontecer. Ver-se e se assumir como um "Corpo-Acontecimento" é não suportar a estagnação que as expectativas do mundo sobre nós, das nossas escolas sobre nós, nos impõem.

A questão aqui passa a centrar-se na ideia do desejo. É o desejo que nos move. Contudo, quando já nos ensinam o que devemos e como devemos desejar retira-se o desejo de seu campo de imanência, arranca-se o desejo de nós enquanto potencialidade criativa e motor de vida, e nos é devolvido um desejo que visa a um "eu" absoluto específico.

Cada vez que o desejo é traído, amaldiçoado, arrancado de seu campo de imanência, é porque há um padre por ali. O padre lançou a tríplice maldição sobre o desejo: a da lei negativa, a da regra extrínseca, a do ideal transcendente (Deleuze; Guattari, 1996, p. 15).

O campo de imanência não é interior ao eu, mas também não vem de um eu exterior ou de um não-eu. Ele é antes como o Fora absoluto que não conhece mais os Eu, porque o interior e o exterior fazem igualmente parte da imanência na qual eles se fundiram (Deleuze; Guattari, 1996, p. 18).

Ora, diferente do que nos quiseram fazer acreditar, desejo não é falta, desejo não é prazer e desejo não é impossibilidade. $E$, no entanto, quantas vezes em nossos processos educacionais não ouvimos sentenças do tipo: "Falta isto para você alcançar as nossas expectativas. Continue buscando!" e aí acabamos indo atrás de um ideal que nunca poderá ser alcançado por completo e nos castramos naquilo que somos. Ou ouvimos: "Você tem desejo demais, descarregue isso de alguma forma!" e depois de descarregarmos as nossas vontades e motivações nos sentimos satisfeitos e não somos realimentados a continuar desejando, pois já chegamos ao lugar ideal e ali ficamos estagnados. Ou, por fim, ouvimos a máxima drástica de que é impossível sermos o que desejamos ser e morremos internamente ao acreditar nisso, passando a ser realmente apenas o que o "outro" deseja que sejamos.

Quantas vezes cenários como esses se tornam comuns no cotidiano das relações educacionais? Nesse sentido, qualquer desejo em se construir e em se desconstruir, em se fazer e em se refazer, é retirado drasticamente de seu campo de imanência, de nossos corpos e subjetivações próprias, para ser direcionado a um ideal de Corpo: o Corpo-Organismo. O desejo é retirado de seu próprio processo e direcionado para um ideal específico. Um ideal de corpo do qual já se conhece tudo, se tem total previsibilidade e controle, cujos órgãos sempre trabalharão da mesma forma e desempenharão as mesmas funções, exceto se vierem a adoecer. O corpo é retirado de seu acontecimento e isso é de uma violência absurda.

$\mathrm{O}$ "eu", nesta perspectiva, tende a ser um modelo esperado e não uma construção particular. Não é visto como processo e devir, mas como algo congelado, engessado, a qual se chega e do qual não se pode mais sair. Quando se delimita o "eu" o corpo é preenchido de subjetivações próprias, e este preenchimento, ora e outra, gera vazios para novos preenchimentos, ou seja, a delimitação do "eu" deveria ser dinâmica, pois o corpo o é. Contudo, quando já se espera um modelo e o tem como 
parâmetro de identidade o "eu" torna-se algo extremamente rígido em seus próprios limites, não se permitindo espaços vazios novos a serem preenchidos e muito menos um extravasamento deste limite. Nesse sentido, o corpo deixa de ser o que ele é - Corpo-Devir (na visão de Nietzsche) e Corpo-sem-Órgãos (na visão de Deleuze e Guatarri) - para ser o Corpo-Organismo tão difundido pelo pensamento cientificista moderno.

\section{A noção de devir e movimento: um contraponto ao "Corpo-Es- tagnado"}

Foi Nietzsche um dos grandes pensadores a gritar contra qualquer determinação humana dada pela religião ou pela ciência: "Eu sou todo corpo e nada além disso; e alma é somente uma palavra para alguma coisa no corpo" (Nietzsche, 1998, p. 60). Foi ele a exaltar o corpo outrora menosprezado ante os discursos da racionalidade. $O$ corpo é visto por ele de maneira totalmente diferente da visão de Corpo-Organismo na medida em que ele se preocupa não em definir o corpo de uma forma ou de outra, mas em percebê-lo em sua dinâmica própria que o transfere da esfera da entificação para a esfera do devir. O corpo para Nietzsche é Corpo-Devir. Corpo em movimento. Corpo em acontecimento. O ser só é nesta dinâmica da vida.

O conceito de subjetividade carnal, de subjetividade corporal, longe da tradição idealista e substancialista, partindo da concepção nietzschiana de corpo, destaca a condição do homem concreto, da experiência vivida, valorizando um saber singular, do absolutamente pessoal. Nietzsche mostra a possibilidade de pensar o singular, o corporal, o instintivo, sem renunciar o pensamento comunicável. Longe de sustentar um pensamento abstrato que se impõe por generalização, por impessoalidade, a subjetividade carnal propõe a universalidade do absolutamente singular (Barrenechea, 2011, p.14).

\section{A estagnação sendo colocada em questão}

Diversos pensadores beberam desta fonte de pensamento e estudaram o corpo e o mundo a partir desta perspectiva. Deleuze trouxe a concepção de Corpo-sem -Órgãos ( $\mathrm{CsO}$ ), justamente aquela que se opõe à ideia de corpo enquanto Organismo. Nesta concepção o que importa não é entender como o corpo funciona, e sim perceber o que pode atravessá-lo e modificá-lo a cada novo movimento. O que importa para esta concepção não é aquilo que se repete e garante uma previsibilidade, é justamente aquilo que desestabiliza e perde a função, é o imprevisível.

Um $\mathrm{CsO}$ é feito de tal maneira que ele só pode ser ocupado, povoado por intensidades. Somente as intensidades passam e circulam. Mas o CsO não é uma cena, um lugar, nem mesmo um suporte onde aconteceria algo. Nada a ver com um fantasma, nada a interpretar. $\mathrm{O}$ CsO faz passar intensidades, ele as produz e as distribui num spatium ele mesmo intensivo, não extenso. Ele não é espaço e nem está no espaço, é matéria que ocupará o espaço em tal ou qual grau - grau que corresponde às intensidades produzidas [...] Por isto tratamos o CsO como o ovo pleno anterior à extensão do organismo e à organização dos órgãos, antes da formação dos estratos, o ovo intenso que se define por eixos e vetores, gradientes e limiares, tendências dinâmicas com mutação de energia, movimentos cinemá- 
ticos com deslocamento de grupos, migrações, tudo isto independentemente das formas acessórias, pois os órgãos somente aparecem e funcionam aqui como intensidades puras (Deleuze; Guattari, 1996, p. 13).

Corpo e vida, nesta concepção, se misturam. Torna-se extremamente importante a compreensão do corpo dentro e a partir daquilo que ele próprio vive. Isto exige um olhar não apenas externo, daquele que observa de fora, mas um olhar capaz de sentir desde dentro deste mesmo corpo observado. É o corpo falando de si mesmo em vez de ser interpretado pelo outro distanciado. É o olhar imerso e não o olhar neutro.

Ao trazer a voz a diferentes corpos-marginais (que a nossa sociedade trata facilmente como corpos desviantes ou doentes), o corpo-esquizo, o corpo-masoquista, o corpo-drogado, entre outros, Deleuze consegue construir não uma interpretação externa sobre essas falas, mas uma compreensão inerente a elas próprias na medida em que entende esses corpos não em suas funcionalidades padrões e nem em suas entificações, mas enquanto devir, enquanto movimento, enquanto disfuncionalidades, na medida em que se deixam modificar pelas intensidades que os atravessam. Essas disfunções não significam doenças ou distúrbios, e ele levanta a hipótese de que doente talvez seja a própria sociedade, que compreende esses corpos enquanto doentes.

A questão está para além de interpretar e criar significados para o corpo; está em deixar o próprio processo e o próprio acontecimento vivido pelo corpo falar; é deixar a experimentação dizer enquanto se faz. A questão está no campo de imanência, no momento presente, e não em algum campo neutro externo e num momento posterior ao vivido. De alguma forma aprendemos a nos posicionar ante a vida numa perspectiva sempre futura e vivemos o instante presente com um pé no lugar posterior a ele. Fazemos isso porque queremos ter controle de onde estamos indo e esquecemos que podemos fazer um caminho diferente: com os dois pés no presente ter condições de pensar sobre o futuro sem querer controlá-lo.

Essa perspectiva resgata o processo em detrimento do resultado. $O$ resultado não é desprezado; existem sim expectativas pessoais e particulares na vivência de algo, contudo, esse resultado e essas expectativas não servem para determinar o processo de uma maneira determinista. A educação moderna parece ter feito o caminho inverso: ao focalizar um resultado específico necessitou fechar o processo também sob alguma forma de ser e de acontecer, menosprezando as formas particulares de acontecimento.

Foi Artaud, em 1947, o primeiro a gritar guerra aos órgãos: "porque atem-me se quiserem, mas nada há de mais inútil do que um órgão" (Artaud apud Deleuze; Guattari, 1996, p.9). Contudo, a sua guerra não era contra os órgãos em si, mas contra a ideia de Organismo. É uma violência ao Corpo-sem-Órgãos dobrar-se a um Organismo. Isso porque criam-se dentro do corpo compartimentos tão rígidos que impedem que as intensidades produzidas neste próprio corpo, na relação interno -externo, possam circular por ali e gerar uma potência de transformações. Contudo não é tão simples desfazer-se do Organismo, e este processo exige muito cuidado e prudência, pois dependendo da forma como se empreende a fabricação do Corpo- 
sem-Órgãos, pode-se se chegar à morte.

Assim, ele oscila entre dois polos: de um lado, as superfícies de estratificação sobre as quais ele é rebaixado e submetido ao juízo, e, por outro lado, o plano de consistência no qual ele se desenrola e se abre à experimentação [...] Combate perpétuo e violento entre o plano de consistência, que libera o CsO, atravessa e desfaz todos os estratos, e as superfícies de estratificação que o bloqueiam ou rebaixam (Deleuze; Guattari, 1996, p. 21).

É nesta corda bamba que nos situamos ante a vida. Vida sempre foi risco e sempre nos colocou em um balançar que não cessa nunca, indo ora para o lado da organização e ora para o lado da desconstrução. Cessar este balanço significa ficar preso em um desses polos, por isso a vida nunca cessa o seu movimento. Este balançar constante é a melhor imagem para se traduzir a concepção trágica nietzschiana da existência. Segundo Amaral (2002, p. 10), "A vida não ocorre em nenhum dos polos extremados, mas nos 'entres' e nos movimentos balanceados e ritmados que aí podem se efetuar". Estarmos sempre neste movimento nos gera alguns incômodos e nostalgias que nos impulsionam a buscar um ponto fixo, mas parar significa "morrer".

\author{
Figurações-desfigurações \\ Arranjos-desarranjos \\ Formas-informe \\ Limitado-ilimitado \\ Balanço (Amaral, 2002, p. 73).
}

À luz de Nietzsche poderíamos chamar este balanço de Apolo $₫$ Dionísio, à luz de Deleuze poderíamos chamar de Organismo - Corpo-sem-Órgãos. Os nomes para este balanço podem ser vários.

A concepção de corpo como Organismo tende a nos fixar no polo da organização, da previsibilidade e da certeza, na medida em que nos impõe um ideal absoluto de Ser e Existir no mundo. Assim como pronunciou Artaud, mantermo-nos neste polo significa negarmos o corpo que somos; significa, portanto, a nossa morte. Por outro lado, ao se buscar o outro polo, ao buscarmos a superação do Corpo-Organismo e a construção do Corpo-sem-Órgãos, não podemos querer nos fixar no polo oposto; ali haveria também a morte, pois se cessaria o movimento da vida.

Nesse sentido, a construção do Corpo-sem-Órgãos pressupõe a manutenção de um mínimo de camadas e estratos. Não é destruindo todos os estratos que faremos as intensidades fluírem dentro de nós. É preciso que tenhamos algumas estruturas em nosso corpo sobre as quais nos apoiarmos para decidir que tipo de intensidade nos povoa e de que forma ela nos atravessa, senão seríamos novamente seres incapazes de construir a nós mesmos e levados a uma construção aleatória e sem sentido para nós. Este é o desafio da vida e o exercício diário em nossas existências no sentido de assumirmos para nós mesmos a construção daquilo que almejamos ser. $\mathrm{E}$ isso as nossas escolas não nos ensinam.

É necessário guardar o suficiente do organismo para que ele se recomponha a cada aurora; pequenas provisões de significância e de interpretação, é também necessário conservar, inclusive para opô-las a seu próprio sistema, quando as 
circunstâncias o exigem, quando as coisas, as pessoas, inclusive as situações nos obrigam; e pequenas rações de subjetividade, é preciso conservar suficientemente para poder responder à realidade dominante. Imitem os estratos. Não se atinge o CsO e seu plano de consistência desestratificando grosseiramente (Deleuze; Guatarri, 1996, p. 23).

Trata-se de nos questionarmos constantemente: que Corpo-sem-Órgãos queremos construir para nós? Que intensidades queremos fazer atravessá-lo? Falar desta concepção de corpo é falar da multiplicidade. Enquanto o Corpo-Organismo fala daquilo que é uno, o Corpo-sem-Órgãos não se prende a uma única forma de ser e de se fazer, pois ele nunca é um resultado pronto e fechado no qual se chega: ele é sempre movimento. Ao mesmo tempo, o Corpo-sem-Órgãos, ao se opor ao que se estabelece como uno, não nega uma unidade. A unidade é a multiplicidade e, quando dissociamos essas duas dimensões, estamos novamente correndo o risco de nos fixar em um dos lados do balanço e ali perder o nosso corpo.

\begin{abstract}
O pior não é permanecer estratificado — organizado, significado, sujeitado mas precipitar os estratos numa queda suicida ou demente, que os faz recair sobre nós, mais pesados do que nunca. Eis então o que seria necessário fazer: instalar-se sobre um estrato, experimentar as oportunidades que ele nos oferece, buscar aí um lugar favorável, eventuais movimentos de desterritorialização, linhas de fuga possíveis, vivenciá-las, assegurar aqui e ali conjunções de fluxos, experimentar segmento por segmento dos contínuos de intensidades, ter sempre um pequeno pedaço de uma nova terra (Deleuze; Guatarri, 1996, p. 23).
\end{abstract}

Este é o grande desafio colocado a nós: desconstruir paradigmas e concepções de homem e de mundo que sempre nos foram impostos de cima para baixo e de fora para dentro como modelos absolutos. A desconstrução do pensamento sobre o mundo passa pela desconstrução de nossos próprios corpos. É preciso que nos abramos internamente para aquilo que o mundo nos mostra ser: devir e movimento. A vida sempre nos chamou para dançar. Que corpo queremos formar em nossas escolas e que escolas queremos construir para formar este corpo? Esta é a questão que perpetua quando nos propomos a romper com um paradigma ainda persistente e que não nos satisfaz enquanto seres no mundo.

\title{
Um convite para pensar a vida como dança
}

Aceitar o desafio da criação e construção do Corpo-sem-Órgãos significa aceitar o desafio que a vida nos oferece: dançar. É aceitando o devir como parte constituinte de nosso ser no mundo que podemos nos inserir no balanço da vida. Novamente, devir e movimento: palavras-chave que já habitam grande parte de nossos discursos políticos, filosóficos, educacionais, mas que ainda não foram apreendidos de modo a fazerem parte, inerentemente, de nossas ações práticas, cotidianas, de nossas relações. A resistência a todo e qualquer tipo de desconstrução ainda é algo visivel em nossas ações mais simples. Por que esse receio da desconstrução se ela já se propõe como parte integrante de nosso ser?

O receio vem daquilo que discutimos aqui: estamos acostumados a buscar o que é organizado, previsível e controlável, e muitos que experimentaram a descons- 
trução não foram cuidadosos o suficiente para evitar a morte. Temos então essas duas referências fortes que nos levam a optar, mais facilmente, pela manutenção da ordem já vivida e já conhecida. Mantermo-nos Corpo-Organismo se torna mais fácil e seguro, e experimentarmos a construção do Corpo-sem-Órgãos se torna um risco que nem sempre estamos dispostos a assumir. Temos medo que a desconstrução de algo nos leve à desconstrução de tudo, não sobrando nada, nem a nós mesmos.

A vida, no entanto, continua diariamente a nos convidar: vamos dançar? E o frio na barriga aparece tal como quando pulamos de uma montanha com um paraquedas. Não queremos quebrar a cara no chão, mas é deliciosa a sensação de voar. Quando nos permitimos voar, permitimo-nos sentir, na própria pele e na própria carne, sensações inauditas e que só poderiam ser expressas partindo-se da própria experiência vivida e jamais de um olhar distanciado, neutro e externo. Essa expressão também não se limitaria à expressão da palavra, seja ela escrita ou falada, mas se expandiria para outras dimensões corporais. Não é à toa que a arte se torna, aqui, um importante espaço para essas expressividades e, é nesse sentido que as escolas precisam se abrir não apenas para o olhar científico mas, também, para o olhar artístico. Ambos os olhares se completam nas possíveis expressividades do corpo. É preciso que o corpo expresse não apenas aquilo que ele observa, mas expresse aquilo que ele vive. É preciso dar voz àquilo que vivemos.

\footnotetext{
Parafraseando Merleau-Ponty, podemos dizer que o mundo não é só o que pensamos, mas o que vivemos. Porque a dimensão vivida, anterior à simbolização, não se esgota jamais no pensamento. Há sempre uma região que permanece fora do alcance do pensamento e da linguagem. E esta região é o sentimento humano. Por sentimento, entenda-se, assim, a apreensão da situação em que nos encontramos, que precede qualquer significação que os símbolos dão. O sentir é anterior ao pensar, e compreende aspectos perceptivos (internos e externos) e aspectos emocionais. Por isso pode-se afirmar que, antes de ser razão, o homem é emoção (Duarte Jr., 1988, p. 16).
}

Ao corpo parece ser preciso resgatar-lhe a autonomia de falar de si próprio, a partir do que se vive. Segundo Gil (1997, p.13), "A esta docilidade da linguagem equivale uma violência real exercida sobre o corpo: quanto mais sobre ele se fala, menos ele existe por si próprio". Aprendemos a ser a partir do que o "outro" diz sobre nós e por nós e, quando temos a necessidade de nos colocar diante de algo a partir de nós mesmos, nos vem a necessidade de aceitação que advém do olhar do "outro".

Daí que se torna urgente a construção de um olhar artístico para o mundo. Este olhar não nega o olhar científico que já construímos; pelo contrário, agrega-se a ele, ampliando-o na medida em que traz à reflexão (entendida aqui como práxis) o campo do mundo vivido e experienciado, o campo pessoal de quem vive e experiência algo, o campo da carnalidade. Este olhar ultrapassa os limites do corpo enquanto Organismo se enveredando pelas sutilezas do que viemos chamando de Corpo-sem-Órgãos.

É claro que se trata, também, de uma concepção específica do que seja este olhar artístico, pois a arte historicamente adquiriu diferentes olhares e posturas ante o mundo, inclusive aquelas influenciadas pela concepção de Organismo. O olhar artístico de que queremos tratar aqui é o olhar capaz de, mais do que reproduzir a realidade tal qual ela nos aparenta ser como se fosse sempre um objeto externo a nós 
mesmos, criar o novo nesta realidade modificando-a desde dentro, inserindo-se nela de tal modo que se torne difícil distinguir o que somos e o que ela é.

Trata-se do que Duarte Jr. (1997) chama de experiência estética, na qual o homem passa a apreender o mundo e a se relacionar com ele não pela velha relação dicotômica sujeito-objeto (Eu-Isso) e sim, em uma relação na qual mundo e homem se confundem com uma coisa só (Eu-Tu). Trata-se de uma relação não hierarquizada e sim totalizadora, uma relação não em terceira pessoa, mas em primeira pessoa. É na e pela experiência estética que o corpo traz aquilo que é seu, suas questões mais íntimas e profundas e, a partir disso, constrói novas realidades.

\begin{abstract}
Na experiência estética "o cotidiano é colocado entre parênteses e suspenso. Suas regras são abolidas. Por um momento o princípio do prazer coloca diante de nós a criação, que nos envolve carinhosamente. O mundo real parou. Desfez-se. Do ventre estéril surge uma nova realidade com que nos embriagamos misticamente". Esta é a experiência estética: uma suspensão provisória da causalidade do mundo, das relações conceituais que nossa linguagem forja. Ela se dá com a percepção global de um universo do qual fazemos parte e com o qual estamos em relação (Duarte Jr., 1988, p. 91).
\end{abstract}

É a partir do pessoal, do sensível, do corporal, do vivido que podemos alçar voos sem medo de cair; que podemos, enfim, aceitar o convite da vida e simplesmente dançar. É através e a partir daquilo que nos toca, que nos rasga por dentro e que nos expõe a carne, que podemos nos reconstruir constantemente, sem a preocupação em ter que atender a determinadas expectativas externas. Nós próprios criamos e recriamos os nossos sentidos.

Poderíamos, também, optar por viver sem sentido algum. Isso nos libertaria do sentido único que o mundo nos atribui, enquanto Organismo, contudo nos deixaria à mercê de outros sentidos que chegariam até nós de cima para baixo e de fora para dentro. Também não seríamos, assim, construtores de nossas próprias histórias: alguém as escreveria por nós e em nosso lugar.

Dançar não significa deixar nosso corpo ir conforme dita a música ou conforme o embalo da maré. Dançar é negar qualquer tipo de imposição na forma de ser e de se expressar, é negar qualquer ausência de vontade de se mexer, e se movimentar a partir daquilo que já se movimenta internamente; é criar. Dançar é também viver, e viver, para Nietzsche, é vontade criadora.

Criar é colocar a realidade como devir, isto é, aos olhos do criador não há mundo sensível já realizado onde é preciso se integrar. Criar não é buscar. Não é buscar um lugar ao sol mas inventar um sol próprio. "Não quero prosseguir", diz Zaratustra, "não sou daqueles que buscam, quero criar para mim meu próprio sol" (Dias, 2011, p. 66).

Se tem algo que a maioria de nossas escolas não fazem é instigar uma vontade criadora em nós. Estão muito mais preocupadas em manter o que já existe, em assegurar determinados resultados, do que em permitir a experiência estética, os processos individuais e estimular a potência criativa. Tudo o que parte do corpo, enquanto matéria de sentimento, tende a ser tratado como desvio. Quantos alunos não são enviados à coordenação como forma de castigo ou como forma de controle quando, 
de repente, se negam a fazer determinada atividade proposta, ou fazem a proposta de uma forma diferente da esperada?

Claro que existem casos e casos em que esta negação ou subversão do que é solicitado aos alunos acontece. A ação e tentativa de castigo ou controle, no entanto, nunca foram e nunca serão possibilidades de se ouvir este corpo que vive, com intensidade, diversas questões internas.

Quantas vezes nos foi permitido na escola trabalhar, crescer, aprofundar sobre nossas próprias questões? Quantas vezes nossos métodos de ensino nos estimularam a experimentar algo por conta própria e disso tirar nossas próprias conclusões, sentidos e significações, sem julgar, de antemão, o que é certo e o que é errado? Quantas vezes fomos estimulados a nos responsabilizar pelo nosso próprio processo de aprendizagem? Não aprendemos a nos responsabilizar sobre nós mesmos e a construir nossos processos individuais na relação com o outro; aprendemos sim a ser tutelados, controlados o suficiente para assegurar que estamos indo rumo a um resultado específico. Aqui, cabe a pergunta: isso é dançar?

\section{A improvisação enquanto concepção de dança - mais do que uma simples questão de técnica}

O bailarino, para estar inteiro em um processo de improvisação, precisa ampliar a percepção de tudo o que acontece à sua volta, bem como a percepção de si mesmo. Precisa aprimorar a habilidade de realizar a leitura e decodificação dos sinais emitidos pelo corpo, e ele treina isso observando-se em sua própria vida cotidiana, e observando também as outras pessoas. [...]. Tudo isso consiste em exercício para ampliar sua percepção, o que vai auxiliá-lo quando for realizar seu trabalho de criação na dança, na construção de personagens [...], simplesmente porque são extraídas da realidade viva e atualizada deste bailarino observador (Andraus, 2015, p. 196).

A improvisação, na dança, pode ser entendida por uns como mera etapa do processo criativo para levantamento de materiais; ela é, no entanto, concebida por outros como lugar de potência para investigação no próprio ato cênico - e é a partir deste pressuposto que propomos pensar a improvisação enquanto concepção de dança que transcende uma visão tecnicista da técnica, para conectar-se à vida. O bailarino improvisador depende de percepção de si mesmo e do entorno, em sua busca incessante de trazer a vida para dentro da cena.

A improvisação cênica se coloca como possibilidade de se conceber o que seja dança, na medida em que se aproxima das concepções de corpo que temos discutido neste trabalho e que se contrapõe ao corpo que nossas escolas e nossa sociedade vêm formando e construindo ao longo da história.

A improvisação não é salvação de nada, é simplesmente uma lente possível, dentre muitas outras, por onde podemos olhar para o corpo que dança. Tampouco a improvisação é uma simples técnica a ser ensinada e aprendida como outras técnicas de dança quaisquer; mais do que isso, a improvisação é o exercício vital de se arriscar com o corpo rumo à indeterminação que ele é, ou seja, é uma atitude do corpo perante si mesmo e diante do mundo, assumindo-se enquanto devir. Esta atitude não é ensinada por nenhuma escola e não é assegurada por nenhuma técnica. Ela é 
uma construção diária de desprendimento de papéis, de funções, de identidades, de subjetivações e significações dadas para nós de fora para dentro a partir de um ideal transcendente; é a imersão no profundo oceano obscuro que é o nosso próprio campo de imanência. Esta atitude diante do mundo é uma atitude corporal e, também, política.

Um improvisador não precisa ser um bailarino ou um artista de qualquer outra área; ele pode ser um cientista, um analfabeto ou qualquer outra pessoa. Como, também, podemos estar diante de um bailarino que nunca fez algum trabalho de improvisação e que sempre dançou movimentos coreografados, ou seja, movimentos estabelecidos previamente ao ato de dançar e, de repente, estamos vendo um improvisador na medida em que ele assume aqueles movimentos preestabelecidos como se fosse a primeira vez que os realiza. Seu corpo abarca uma movimentação já conhecida como se nunca a tivesse feito antes. É neste lugar, o lugar do instante presente, que entendemos a improvisação e o corpo que improvisa; a partir daí que chamamos este corpo de "Corpo-Acontecimento", que se contrapõe ao "Corpo-Estagnado" a que nos referimos no início do texto.

\section{A obra de Henri Cartier-Bresson e imprevisibilidade na fotografia e na dança}

Ao entrar em contato com algumas fotografias de Henri Cartier-Bresson e com um pouco de sua história de vida, foi possível nos deparar com a personalidade de um grande improvisador, e com um entrelace existencial entre o artista e a sua obra, entre arte e vida, de tal modo que a dissociação entre o Cartier-Bresson humano e o Cartier-Bresson fotógrafo chega ao lugar do imperceptível.

Percebe-se neste grande artista anseios e buscas pertinentes à área da dança. Há um diálogo possível entre as fotografias específicas deste fotógrafo, bem como sua concepção de mundo e de vida, e o corpo que improvisa em dança. Fazer arte está extremamente atrelado ao existir (sentir e pensar), ao que grita forte dentro do artista, ao que o atravessa e o move a cada instante em que existe. $O$ improvisador não é, justamente, um "sujeito dos instantes"?

Este é também um ponto de convergência com o conceito de "Corpo-sem -Órgãos" de Deleuze e Guattari, conceito este que distancia o corpo de todas as ideias forjadas sobre ele ao longo dos anos, fincando-o naquilo que ele mostra ser no momento presente: um constante devir, um constante fluxo de energias que não se controla a priori. Basta criarmos um "Corpo-sem-Órgãos" para que este seja atravessado por suas correspondentes formas de intensidades que estão sempre a modificá-lo e a transportá-lo para novas sensações, percepções e terrenos - lugares de instauração do campo de imanência do desejo que sempre nos move. Ou seja, por mais que venhamos a construir e a nos assentar sobre estratos e linhas bem definidas, nossos corpos vivem o constante movimento da desestratificação e da desterritorialização; vivem sempre no "entre" dos terrenos já edificados e conhecidos. O plano de fuga é o plano do desejo.

Quando um improvisador surge e se coloca, seja na cena da vida ou na cena estrita de uma atuação artística, ele é, justamente, esse sujeito dos instantes, esse 
construtor de terrenos a serem habitados e desabitados, essa imanência do que se deseja e se busca, esse agenciador de intensidades. $O$ improvisador nunca está satisfeito, nunca encontra o seu lugar seguro: ele está sempre em movimento e no lugar do "entre", do risco de se encontrar e de se perder.

\section{O improvisador e a ideia de "Corpo-Acontecimento"}

Quando improvisamos na dança o que temos diante de nós? Temos um lugar a ser construído, um lugar a ser mapeado. Não se trata de um lugar externo ao corpo, mas de um lugar onde a dualidade corpo-espaço, interno-externo, já não existe, já não é uma questão a se considerar. O que existe, sim, é um campo de ação permeado por uma multiplicidade de forças que o atravessa num fluxo contínuo de energia. Captar esse fluxo energético, reconhecer essas várias forças atuantes, atuar desde dentro delas agenciando-as é o papel do corpo que improvisa. É no instante do acontecimento que o improvisador atua a partir e através do seu próprio corpo e das possíveis relações que o tangenciam. O improvisador é, antes de tudo, o construtor do seu tempo e do seu espaço, é um atualizador de virtuais como um flâneur a mergulhar naquilo que observa ou um antiviajante a se deixar levar sem guias.

É este um dos nomes dados pelo biógrafo Assouline (2008) ao escrever sobre a vida do fotógrafo francês Henri Cartier-Bresson.

O antiviajante dentro dele se manifesta em sua recusa de viajar. Ele não viaja, ele se desloca. Lentamente, se possível, pois precisa tomar o tempo de perder seu tempo. O tempo não importa mais. Cartier-Bresson se instala, se fixa e se faz esquecer. O estado de graça, possível somente àqueles que não o buscam, também é uma questão de disponibilidade. Cartier-Bresson ronda a surpresa a todo instante, mas nunca a espera. Seu único compromisso é com o acaso que nunca marca hora. É por isso que se mantém receptivo, estado propício aos encontros mais fulgurantes. Desejo insensato este de querer reter a vida, manipular o intemporal, dominar a eternidade (Assouline, 2008, p. 80).

Cartier-Bresson abraça uma vida de improviso. O seu olhar aberto e atento, ao mesmo tempo que despreocupado e despretensioso acerca de qualquer possibilidade de encontro, o faz encontrar a tênue linha do instante decisivo no simples click de sua máquina fotográfica. Cada fotografia é uma surpresa deste encontro que nos faz duvidar de que nada ali foi premeditado, calculado, escolhido e definido com antecedência. Imerso no instante do acontecimento, Cartier-Bresson fixa, na forma de fotografias, imagens extremamente dinâmicas e vivas. Um segundo depois daquele instante essas imagens já não seriam possíveis de serem captadas e fixadas por sua máquina fotográfica.

São fotos de um flâneur despreocupado, que não espera nada e não é esperado por ninguém. Semelhante desprendimento das contingências do cotidiano faz com que ele confira à sua pequena máquina fotográfica a suprema liberdade de perscrutar os rumores do mundo, fuçando nos escombros do inconsciente. Como se buscasse com obstinação expressar aquilo que a consciência ainda não organizara... (Assouline, 2008 p. 79). 
É nesse sentido que as fotografias de Cartier-Bresson parecem dançar diante de nossos olhos. A dança não está exatamente no resultado imagético produzido, mas no seu olhar que, diante de um infinito campo de possibilidades de composições e agenciamentos de forças, conseguiu encontrar o instante decisivo, o lugar do que é imprevisível, o lugar da surpresa, e agir desde dentro deste lugar como se fosse parte dela, inerente a ela. Por mais que este fotógrafo se coloque como observador da vida ele só consegue captá-la criando nela um campo de imanência para a sua ação.

Este campo de imanência não se importa com o tempo passado ou o tempo futuro, mas circunscreve passado, presente e futuro em um único e mesmo ponto e, assim, circunscreve o ser humano enquanto potência criadora. Foi Nietzsche quem pensou a vida como vontade criadora e o ser humano como potência. Ao fazer isso ele elabora uma nova concepção de vida, de tempo e história e de criação. Ele retira o ato de criar dos cânones tradicionais que fixam a criação do mundo num dado ponto temporal e espacial. Para ele, a criação é algo que não se esgota e que por isso não tem nada de fixo. Nesse sentido, ele insere o ser humano em um tempo presente pois é no presente que o passado e o futuro estão; ele insere o ser humano no instante do acontecimento enquanto um sujeito que cria a vida sem interrupções, simplesmente existindo.

É uma nova maneira de se pensar que se aplica ao devir, opõe-se à metafísica, que busca o estável e a permanência. O perene não é o sujeito criador, nem o objeto criado, mas uma ação, uma ação contínua, um fluxo de vida constante. Nietzsche deixa claro esse pensamento quando escreve na primeira dissertação da Genealogia da moral que "não há um ser por trás do fazer, do atuar, do devir; [...] a ação é tudo"... Criar é colocar a realidade como devir, isto é, aos olhos do criador não há mundo sensível já realizado onde é preciso se integrar. Criar não é buscar. Não é buscar um lugar ao sol, mas inventar um sol próprio (DIAS, 2011, p. 65).

O ser humano cria no instante do acontecimento daquilo que vive. $O$ improvisador é esse homem presentificado, atualizado e atuante no aqui e no agora, e que faz compor as diversas forças intensivas que o circundam, como na obra de Cartier-Bresson. O fotógrafo parece desejar encontrar a ordem no meio do caos que é a vida. Ele deseja encontrar a composição e a geometria nas quais a transformação é uma constante. Mas ele deseja isso sem buscar um ideal transcendente, sem uma projeção exterior, sem um padrão ou modelo ao qual seguir. Ele experimenta, explora, realiza um movimento muito mais de expansão para o imprevisível do que de recolhimento para terrenos já conhecidos. Por isso ele não está a serviço de uma técnica, mas utiliza e explora tudo o que aprendeu, desde o contato com a pintura e com seu mestre Lhote até as influências do surrealismo (que sempre estiveram presentes de uma forma ou de outra) para encontrar aquilo que seria seu. A cada vez que lança o seu olhar sobre a vida ele o faz como se fosse a primeira vez.

E não seria, justamente, este o grande desafio do improvisador que dança? Entrar em cena, a cada vez, como se fosse a primeira? Só assim é que seria possível partir do que está ali vivo, atuante e presente, e não do que está de fora em matéria de transcendência.

Quando Deleuze e Guattari (1996) escrevem sobre o "Corpo-sem-Órgãos", eles falam sobre um corpo que se opõe a todo e qualquer modelo externo a ele. 0 
"Corpo-sem-Órgãos" se faz enquanto experimentação e nele jamais se chega. É um constante processo, um constante devir. O tempo todo estamos agenciando, construindo e desconstruindo os fluxos e os canais inerentes ao nosso corpo. Somos, constantemente, atravessados por diferentes intensidades a cada vez que forjamos um "Corpo-sem-Órgãos" dentro de nosso campo de experimentação. Quebra-se, aqui, a ideia de Corpo como Organismo, no qual tudo tem o seu devido lugar e a sua devida função. Abre-se um amplo campo de possibilidades de o corpo se fazer enquanto acontecimento no mundo, enquanto campo de imanência de desejo que o insere de forma presentificada e atuante no mundo. $O$ corpo se faz e a ele nunca se chega ou se termina de chegar.

[...] mas de todo modo você faz um, não pode desejar sem fazê-lo - ele espera por você, é um exercício, uma experimentação inevitável, já feita no momento em que você a empreende, não ainda efetuada se você não a começou. Não é tranquilizador, porque você pode falhar. Ou às vezes pode ser aterrorizante, conduzi-lo à morte. Ele é não-desejo, mas também desejo. Não é uma noção, um conceito, mas antes uma prática, um conjunto de práticas. O Corpo sem Órgãos não se chega, não se pode chegar, nunca se acaba de chegar a ele, é um limite. (Deleuze; Guatarri, 1996, p. 9).

Esta concepção de corpo é, antes de tudo, uma concepção de mundo, de existência e um posicionamento político radical na medida em que se opõe a todo tipo de ideal e de padrão construído historicamente sobre o corpo.

O corpo que improvisa é um corpo que dialoga muito bem com esse conceito na medida em que se coloca sempre aberto e receptivo ao instante em que se insere fazendo-se "Corpo-Acontecimento" e modificando-se a cada novo fluxo que o intercepta. Esse corpo não se preocupa com quem ele seja, não se preocupa em se definir de uma forma ou de outra, não quer se enquadrar em modelo algum, não deseja se encontrar; pelo contrário, este corpo está muito mais interessado em se perder de si mesmo e de qualquer ideal ou modelo, ele quer ser atravessado por diferentes forças, ser devir e não ser entificado. Por isso trata-se também de um corpo poroso, capaz de se abrir e de se fechar para o que quer. Um corpo que decide seus próprios agenciamentos estando sempre em um estado de continuidade e não de conclusão. Um corpo que, também, podendo ser tudo, sabe o que quer - senão ele não aconteceria e seria apenas uma dispersão atômica no espaço.

Quando Cartier-Bresson se abre para uma realidade dinâmica e consegue captar, em lapsos de segundos, uma imagem extremamente composta, ele se abre para o universo das micropercepções de tal modo que a sua consciência torna-se a consciência do corpo, que é o corpo-mundo. A multiplicidade é a questão e qualquer tipo de dualidade não faz mais o menor sentido. Para José Gil:

A consciência do corpo tornou-se antes um universo de pequenas percepções. Para ser exato, a consciência não é "invadida" pelas pequenas percepções: torna-se por inteiro um bloco de miríades de pequenas percepções, bloco que, por seu turno, goza das propriedades das pequenas percepções. Faz-se, por exemplo, vidente... De fato, a consciência do corpo faz-se inconsciente do corpo ou inconsciente de posição: percebe os movimentos e as configurações inconscientes que os corpos deixam entrever como "contornos vazios". O que supõe antes uma percepção "larga": o paradoxo das pequenas percepções é o de apreenderem os 
micro-índices imperceptíveis que acompanham as macro-percepções e, ao mesmo tempo, captarem as vastas configurações que ultrapassam a escala das macro -percepções médias. A razão de ser assim é simples: apreender "uma" pequena percepção é apreender mil, porque elas fazem bloco, aglutinam-se em conjuntos incomensuráveis (Gil, 2004, p. 131).

Improvisar, portanto, é ser consciente, mas consciente de corpo. O universo das micropercepções situa o corpo numa relação intrínseca com o mundo, e não mais dualística, de tal modo que já não se sabe mais onde começa um e onde termina o outro. O que existe é uma gama de possibilidades infinitas de conexões que não acabam nunca de serem produzidas. É de dentro dessas conexões, é imerso neste campo de imanência do desejo, que o corpo não cessa de produzir. E ele não produz ou se move em nome de uma falta que precisa preencher ou de um prazer que precisa ser descarregado ou ainda buscando um ideal transcendente, um modelo no qual se pautar. Pelo contrário, ele não busca nada absolutamente. Ele não se define dentro de um caminho com uma linha de chegada ou um ponto final. Ele se define sempre nos espaços do "entre" e do "meio", nos espaços infinitos de interconexões e energias flutuantes que não cessam, ele é um continuum. $\mathrm{E}$, como nos dizem Deleuze e Guattari, "É desde logo uma questão de semiótica perceptiva. Não é fácil perceber as coisas pelo meio, e não de cima para baixo, da esquerda para a direita ou inversamente: tentem e verão que tudo muda" (Deleuze; Guatarri, 1995, p. 34).

Se estamos falando de uma forma de olhar o mundo e estamos trazendo, justamente, a visão de um fotógrafo que carrega dentro de si esta forma de olhar a vida, e se estamos dizendo que assumir esta forma de olhar o mundo em que vivemos não é algo nada fácil, estamos esbarrando em um outro conceito extremamente interessante de Deleuze e Guattari, que é o conceito de minoria. Pessoas que olham para a vida como o momento presente, como um processo não cumulativo nem evolutivo, mas feito de constantes recomeços são a minoria neste mundo.

Diferente do que se pensa, no entanto, a questão minoria/maioria não é uma questão quantitativa na visão desses autores, e sim uma questão de contraponto, em que a maioria se remete a um padrão (o padrão majoritário) e as minorias se remetem ao devir (devir minoritário). Tudo o que não se iguala ao padrão estabelecido é porque está em movimento, e não porque se construíram outros pequenos e diferentes padrões. Ou seja, olhar a vida pelo viés e pela perspectiva do "entre" e do "meio", pela perspectiva do continuum e dos constantes recomeços, é um devir minoritário neste mundo onde o padrão majoritário é olhar a vida por uma lente determinística.

Minoria e maioria não se opõem apenas de uma maneira quantitativa. Maioria implica uma constante, de expressão ou de conteúdo, como um metro padrão em relação ao qual ela é avaliada. Suponhamos que o constante ou metro seja homem-branco-masculino-adulto-habitante das cidades-falante de uma língua padrão-europeu-heterossexual qualquer... Uma outra determinação diferente da constante seria então considerada como minoritária, por natureza e qualquer que seja seu número, isto é, como um subsistema ou como fora do sistema. Isso pode ser visto em todas as operações, eleitorais ou não, onde se dá o poder de escolha, com a condição de que a escolha permaneça conforme aos limites da constante ("você não tem que escolher uma mudança de sociedade..."). Mas, nesse ponto, tudo se inverte. Pois a maioria, na medida em que é analiticamente compreendida no padrão abstrato, não é nunca alguém, é sempre Ninguém - Ulisses -, ao passo 
que a minoria é o devir de todo o mundo, seu devir potencial por desviar do modelo (Deleuze; Guatarri, 1995, p. 52).

O improvisador também se constitui como uma devir minoritário na medida em que não está à caça de nenhum modelo ou padrão, de nenhum caminho prescrito que possa percorrer; ele simplesmente está ali, como corpo presente e em acontecimento, totalmente imerso e aberto a qualquer surpresa e imprevisto. Ele está ao invés de ser, ele não busca ser nada. Esta não é a sua preocupação, simplesmente. Seu olhar está voltado para o indeterminado. É no campo da indeterminação que ele atua agenciando formas atrás de formas, construindo e desconstruindo territórios, mapeando e cartografando, experimentando, sentindo e flutuando. É nesse estado de corpo que ele conseguirá, afinal, ser. Um ser-devir-desviante. Ser acontecendo. Corpo-Acontecimento.

\section{Referências}

AMARAL, Maria Regina Faria do. Aprendendo a dançar - entre a forma e o devir. São Paulo: Annablume, 2002.

ANDRAUS, Mariana Baruco Machado. Kungfu/Wushu: Luta e Arte. 2.ed. Curitiba: Prismas, 2015.

Conceituando luta: ética marcial, conflito, efemeridade e construção de sentido. In: ANDRAUS, Mariana Baruco Machado Andraus. Arte marcial na formação do artista da cena. Jundiaí: Paco Editorial, 2014.

ASSOULINE, Pierre. Cartier-Bresson: o olhar do século. Tradução: Julia da Rosa Simões. Porto Alegre, RS: L\&PM, 2008.

BARRENECHEA, Miguel Angel de. Nietzsche: Corpo e Subjetividade. O Perceve jo on-line. Vol. 3, n. 2, ago-dez/2011. Disponível na internet: http://www.seer. unirio.br/index.php/opercevejoonline/issue/view/78

CARTIER-BRESSON, Henri. Henri Cartier-Bresson. CLAIR, Jean (Texto de). Tra dução: André Telles. São Paulo: Cosac Naify, 2011.

DELEUZE, Gilles; GUATTARI, Felix. Mil Platôs: Capitalismo e Esquizofrenia. Tra dução: Aurélio Guerra Neto, Célia Pinto Costa. Volume 1. São Paulo: Ed. 34, 1995.

Mil Platôs: Capitalismo e Esquizofrenia. Tradução: Ana Lúcia de Oliveira e Lúcia Cláudia Leão. Volume 2. Rio de Janeiro: Ed. 34, 1995.

Mil Platôs: Capitalismo e Esquizofrenia. Tradução: Aurélio Guerra Neto, Ana Lúcia de Oliveira, Lúcia Cláudia Leão e Suely Rolnik. Volume 3. Rio de Janeiro: Ed. 34, 1996. 
DIAS, Rosa Maria. Nietzsche: vida como obra de arte. Rio de Janeiro: Civilização Brasileira, 2011. (Coleção Contemporânea).

DUARTE Jr., João-Francisco. Fundamentos estéticos da educação. 2.ㄹ ed. Cam pinas: Papirus, 1988.

FOUCAULT, Michel. Vigiar e Punir. Petrópolis: Vozes, 1977.

FREIRE, Paulo. Pedagogia do Oprimido. 17. a ed. Rio de Janeiro: Paz e Terra, 1987.

GIL, José. Movimento Total. São Paulo: Iluminuras, 2004.

Metamorfoses do corpo. Lisboa: Relógio d’Água, 1997.

MORAES, Maria Cândida. O paradigma educacional emergente. Campinas: Pa pirus, 1997.

NIETZSCHE, Friedrich Wilhelm. Assim falou Zaratustra: um livro para todos e para ninguém. Tradução: Mário da Silva. 9a ed. Rio de Janeiro: Civilização Bra sileira, 1998.

PORTOCARRERO, Vera. Instituição escolar e normalização em Foucault e Can guilhem. Educação \& Realidade, v. 29, n. 1, jan/jun. 2004, pp. 169-185. Disponí vel em: http://www.seer.ufrgs.br/educacaoerealidade/article/viewFi le/25424/14750 Acesso em 08 jul. 2016.

SILVA, Hugo Leonardo da. Poética da oportunidade: estruturas coreográficas abertas à improvisação. Salvador: EDUFBA, 2009.

Recebido em: 25/07/2015

Aprovado em: 11/07/2016 